\title{
MINERALS AND CRITICAL RAW MATERIALS: POTENTIAL AND OPPORTUNITIES FOR ARGENTINA
}

\author{
Diego Murguía \\ CONICET / Interdisciplinary Institute of Political Economy, \\ Faculty of Economic Sciences, University of Buenos Aires \\ Autonomous City of Buenos Aires, Argentina \\ diegomurguia@yahoo.com.ar \\ Reception date: 03/02/2021 - Approval date: 04/12/2021 \\ DOI: https://doi.org/10.36995/j.visiondefuturo.2021.26.01.003.en
}

\section{ABSTRACT}

"Critical" minerals and raw materials are usually defined as those that present great economic importance and high risk of supply disruption. Their integral use (mining, reuse and recycling) opens a window of opportunity for resource-rich countries such as Argentina. Based on a bibliographic review, this work presents an overview of the potential of critical materials and public policies to promote their use under sustainability principles.

The results of historical explorations indicate that Argentina has geological-mining potential of critical minerals. However, new investments are required to value, standardize and digitize the available data. It is also necessary to rank these minerals in the public research agendas and encourage their exploration. The potentiality in secondary resources is difficult to estimate given the lack of data on the generation and recycling of industrial scrap, batteries and other discarded products.

In an international context of growing socio-environmental demands and persistent conflict, achieving a sustainable management of critical (and non-critical) minerals implies overcoming the "extractivist" model. For this, it is essential to transform the nature of the linkages between the mining sector, the scientific-technological system, the local productive network and the communities, as well as the ways of making strategic decisions about their use.

KEY WORDS: Strategic minerals; Extractivism; Mining value chain; Science-production articulation; Waste valorization.

\section{INTRODUCTION}

One of the main positive effects of the covid19 pandemic has been to provide greater political momentum and accelerate the advancement of the United Nations Sustainable Development Goals (hereinafter SDGs) agenda, especially actions to combat climate change. The return of the United States of North America (hereinafter the US) to the Paris 
Agreement is aligned with the policies that Europe and China have been implementing to accelerate the decarbonization of their energy matrices. The United Nations recognizes the fundamental importance of the mining sector for modern life and affirms that its sustainable management will contribute significantly to the achievement of the SDGs and their targets, including the energy transition (ANUMA, 2019). Projections indicate that between 2020 and 2060 the global extraction of metallic and non-metallic minerals will multiply by 2.5 and 1.8 times respectively (OECD, 2019) and that a large part of this increase will be due to the energy transition, which will be very intensive in the use of minerals such as graphite or copper. For example, it is estimated that the production of graphite, lithium, and cobalt will increase more than $450 \%$ by the year 2050 (Hund et al., 2020).

While mineral extraction remains essential to achieving the SDGs, mining will continue to generate conflicts, pressures and socio-environmental impacts in the regions where the resources are located. Since the second half of the 20th century, the specialization of countries in sectors that are intensive in natural resources has been considered a "curse" by different schools of thought, including economic ${ }^{1}$ and political-institutional theories. According to the latter, the negative relationship between natural resources and economic development is attributed to the lack of "good governments" regarding how the rents from natural resources are appropriated, distributed and used (Ross, 1999). Today, in a global resource governance framework of a multi-level and multi-stakeholder nature (Bache and Flinders, 2004), there is a call to improve the governance architecture (Ali et al., 2017). For this, new coordination mechanisms are necessary that allow decoupling economic growth from the use of natural resources, without going beyond the "planetary boundaries" (Steffen et al., 2015).

Mining companies have widely adopted, at least in their sustainability reports ${ }^{2}$, the rhetoric of the SDGs and seek to align their activities with them. Regulators are also driving change: the European Commission has established as a fundamental pillar of its strategy to increase resilience in the supply of raw materials, the diversification of its supply through responsible imports ${ }^{3}$. In London, the Metal Exchange has introduced responsible sourcing requirements for its approved brands. These types of regulations establish a global standard with implications for producing countries such as Argentina, since the implementation of measures and their certification are required. In response to these requirements, Chile promotes the concept of "green mining" through which energy and water efficiency are

\footnotetext{
1 For example, in the 1950s, the Prebisch school attributed poor economic performance to the deterioration of the terms of trade for products based on natural resources.

${ }^{2}$ A recent report by the RMF and the CCSI found that most of the mining companies analyzed only prioritize the SDGs superficially and that much of the reporting on the SDGs appears to be "cosmetic" (RMF and CSSI, 2020).

3 See COM (2020) 474 final.

"Visión de Futuro" Año 19, Volumen No 26 No 1, Enero - Junio 2022 - Pág 105 - 122

URL de la Revista: http://visiondefuturo.fce.unam.edu.ar/index.php/visiondefuturo/index

URL del Documento: https://visiondefuturo.fce.unam.edu.ar/index.php/visiondefuturo/issue/view/22

ISSN 1668 - 8708 - Versión en Línea

E-mail: revistacientifica@fce.unam.edu.ar
} 
encouraged and traceable methodologies are applied to certify improvements (Alta Ley, 2019).

In a global context of new geopolitical tensions, growing demand for minerals and persistent socio-environmental conflicts $^{4}$ associated with mining, the large mineral consuming countries identify those raw materials essential for defense, national security and the functioning of their industries and economies. Both the European Commission, the US, Canada and Australia have classified as "critical" those raw materials with great economic importance and potential for disruptions in their global supply. As recognized by the European Commission in the new European Green Deal ${ }^{5}$, access to resources, especially critical raw materials, is a strategic security issue to meet its ambition to achieve climate neutrality by 2050. Similarly, in March 2021, Brazil instituted a policy to support the environmental licensing of projects for the production of "strategic minerals" (Decree 10,657 / 2021) which are defined as i) those where Brazil has a high import dependence in key areas of the economy (e.g., potash for fertilizers), ii) those of importance for use in high technology industries and iii) those with essential comparative advantages for generating a surplus in the trade balance (e.g., iron, niobium).

The identification of critical raw materials represents a new opportunity for resourcerich countries like Argentina. However, seizing such opportunity requires that the mining sector adapts to international requirements and advance on the challenges that weigh on its competitiveness $^{6}$. In Argentina, such challenges include economic aspects (taxation, costs, exchange rate, etc.) and infrastructural (energy, logistics, communication, etc.) but also political ones. In this sense, it is necessary to overcome the "extractivist" policy (export of commodities) and the generation of "enclave" economies ${ }^{7}$ in the direction of a development strategy that fosters local technological and productive capacities. Taking advantage of the opportunity implies using minerals as a platform for an innovative industrial development (Roger, 2019) that allows generating dynamic suppliers ${ }^{8}$ and knowledge-intensive linkages with the local productive network. This path will contribute to correcting some of the structural criticisms that underlie socio-environmental conflicts.

The aim of this article is to provide a general overview of the potential of minerals and

\footnotetext{
4 Understood as that linked to the access and control of natural assets and the territory, which imply, on the part of the opposing actors, divergent interests and values (Svampa, 2013).

5 See COM(2019) 640 final.

6 Understood as a multi-variable concept influenced by institutional, economic, social and environmental dimensions (Murguía, 2019).

7 According to the "resource curse" literature, the term refers to countries rich in natural resources whose exploitation generates minimal linkages with the local productive system.

8 Understood as suppliers of goods or services with high technological content and/or technological complexity (e.g. software, engineering, robotics, etc.) (Marín et al., 2020).

"Visión de Futuro" Año 19, Volumen No 26 No 1, Enero - Junio 2022 - Pág 105 - 122

URL de la Revista: http://visiondefuturo.fce.unam.edu.ar/index.php/visiondefuturo/index

URL del Documento: https://visiondefuturo.fce.unam.edu.ar/index.php/visiondefuturo/issue/view/22

ISSN 1668 - 8708 - Versión en Línea

E-mail: revistacientifica@fce.unam.edu.ar
} 
critical raw materials available in the Argentine territory and of public policies necessary for their use under sustainability principles. Among other issues, the latter implies moving from a "mining policy" mainly oriented towards the export of commodities towards a "mineral policy" focused on the integral management of minerals (circular economy) and the development of the mining value chain.

The article is structured as follows: after the methodology, an overview of the potential of critical minerals and materials (primary and secondary or recyclable resources), challenges, opportunities and research needs associated with the potential to generate productive chains is presented. Third, suggestions for public policies are presented to advance in the direction of a responsible mining production. Finally, the article is closed with conclusions.

\section{DEVELOPMENT}

\section{Methodology and scope}

The approach used is based on a bibliographic review and the results of research projects from a perspective that understands the competitiveness of mineral resources as a multi-variable concept. Under this perspective, evaluating the competitiveness of a deposit implies weighing economic variables with institutional, social and environmental variables, including efficiency in the use of resources (Reuter, 2005).

The assessment of the potential of minerals and critical raw materials was carried out based on the review of the data and information available in the results of prospecting and exploration campaigns published in the annals of the Argentine Mining Geological Service (SEGEMAR). This body has the main official national repository of geological data and cooperates with international organizations in the evaluation of the potential of critical minerals. It should be noted that the data available for critical minerals are the product, for the most part (except for lithium and uranium), of historical exploration given that exploration investment in recent decades has been mainly destined to the search for copper, gold and silver (Such, 2018). Another exception is the element indium, recently discovered by researchers from the National Council for Scientific and Technical Research (CONICET) through cooperation with mining companies (Jovic et al., 2015).

The potential of primary resources was compiled in Table $\mathrm{N}^{\circ} 1$ for 19 critical materials and minerals selected from the latest lists prepared by the European Commission (2020, 30 raw materials $\left.{ }^{9}\right)$ and the US Department of the Interior $\left(2018,35\right.$ minerals $\left.^{10}\right)$. Both institutions

\footnotetext{
${ }^{9}$ See https://eur-lex.europa.eu/legal-content/ES/TXT/HTML/?uri=CELEX:52020DC0474\&from=EN

"Visión de Futuro" Año 19, Volumen No 26 No 1, Enero - Junio 2022 - Pág 105 - 122

URL de la Revista: http://visiondefuturo.fce.unam.edu.ar/index.php/visiondefuturo/index

URL del Documento: https://visiondefuturo.fce.unam.edu.ar/index.php/visiondefuturo/issue/view/22

ISSN 1668 - 8708 - Versión en Línea

E-mail: revistacientifica@fce.unam.edu.ar
} 
classify an item as "critical" based on its economic importance and the risk of disruptions in its supply chain. Said selection provides a general, simplified and non-exhaustive panorama of the geological potential and implies excluding minerals of importance for the energy transition that are not classified as "critical" and where Argentina has potential, such as nickel. The selection was made based on those minerals with the greatest potential according to information on reserves in the 2020 yearbook of the US Geological Survey (USGS, 2020) and information in the SEGEMAR resource inventory (Zappettini, 1999c).

The main uses of each mineral and the main source of supply as a secondary resource (recycling rate ${ }^{11}$ ) that appears in Table $\mathrm{N}^{\circ} 1$ were extracted from the documentation of the European Commission (European Commission, 2020a, 2020b). The column "primary resources" details the provinces where the main known deposits and examples are located, based on publicly accessible bibliography, especially based on Gozalvez et al., (2004) for industrial minerals and Zappettini (1999a) for metalliferous. In addition to the 19 minerals mentioned, hydrogen was also included, which, although it is not considered a critical element, is relevant to promote the energy transition.

The potentiality analysis of secondary resources was carried out considering those minerals that can be recycled, that is, whose use is not dissipative, such as antimony. To this was added a reference to the potential that would exist in mining waste contained in nonoperating mines. In Argentina, the potential to recover metals from such facilities is unknown since they have not been considered a potential source of supply and there are no standardized records on the contents.

The review of the historical production background per mineral was made based on SEGEMAR annals (Zappettini, 1999c). Regarding the possibilities of generating productive linkages $^{12}$, the given suggestions are based on the available bibliography which encompasses technical reports and academic articles. The compilation of public policies is based on sectoral analyzes carried out by specialists, recommendations in national plans and European research projects focused on critical minerals, especially based on recommendations from the SCRREEN project (http://scrreen.eu/).

\footnotetext{
${ }^{10}$ See https://www.federalregister.gov/documents/2018/05/18/2018-10667/final-list-of-critical-minerals2018

11 With the exception of vanadium, it refers to the recycling input rate that indicates the fraction of secondary material in the total input that enters into the production of each metal.

12 Following López et al., (2019) they can be backwards, forwards or horizontal (lateral).

"Visión de Futuro" Año 19, Volumen No 26 No 1, Enero - Junio 2022 - Pág 105 - 122

URL de la Revista: http://visiondefuturo.fce.unam.edu.ar/index.php/visiondefuturo/index

URL del Documento: https://visiondefuturo.fce.unam.edu.ar/index.php/visiondefuturo/issue/view/22

ISSN 1668 - 8708 - Versión en Línea

E-mail: revistacientifica@fce.unam.edu.ar
} 


\section{An analysis of the mineral and productive linkages potential}

\section{Primary materials (mining)}

Of the critical materials and minerals analyzed (see Table $N^{\circ} 1$ ), only two are produced in Argentina: borates (natural and refined) and lithium (carbonate and chloride), both in the Puna region and with production of international relevance: Argentina is located as the world's third largest producer of lithium (Jerez et al., 2017) and among the six main exporters of borates (DAPM, 2018). In the future, production could increase even more since the country is among the three countries with the largest lithium reserves and resources (Jerez et al., 2017; USGS, 2020) and has significant borate reserves.

In the case of borates, specifically those that are exported without being processed, the producing companies are oriented to the external market, mainly to Brazil where boron is used as a soil fertilizer. The limiting factor to increase production lies in costs since producers send loads by truck, which represents a cost of almost double compared to producers in Bolivia. This indicates the need to improve the railway infrastructure on the Argentine side. Regarding possible linkages, unlike lithium, borates do present cases of forward linkages along the value chain with companies that have been able to enter high value-added segments, such as Agenor, a small and mid-size company located in Salta (DAPM, 2018).

\footnotetext{
“Visión de Futuro" Año 19, Volumen No 26 N 1, Enero - Junio 2022 - Pág 105 - 122

URL de la Revista: http://visiondefuturo.fce.unam.edu.ar/index.php/visiondefuturo/index

URL del Documento: https://visiondefuturo.fce.unam.edu.ar/index.php/visiondefuturo/issue/view/22

ISSN 1668 - 8708 - Versión en Línea

E-mail: revistacientifica@fce.unam.edu.ar
} 
Table $N^{\circ}$ 1: Overview of critical materials and minerals (selection) in Argentina

\begin{tabular}{|c|c|c|c|c|c|c|c|}
\hline \multirow[t]{2}{*}{ Material } & \multirow{2}{*}{$\begin{array}{l}\text { Main uses, including } \\
\text { relevance to the energy } \\
\text { transition }\end{array}$} & \multirow[t]{2}{*}{$\begin{array}{l}\text { EC list } \\
(2020)\end{array}$} & \multirow[t]{2}{*}{$\begin{array}{l}\text { US list } \\
\text { (2018) }\end{array}$} & \multicolumn{3}{|c|}{$\begin{array}{c}\text { Primary resources } \\
\text { (geological-mining potential) }\end{array}$} & \multirow[t]{2}{*}{$\begin{array}{l}\text { Secondary } \\
\text { resources }\end{array}$} \\
\hline & & & & \multicolumn{2}{|c|}{ Provinces with greater potential, examples } & Source & \\
\hline Antimony & $\begin{array}{l}\text { Vehicle batteries (alloy), flame } \\
\text { retardant }\end{array}$ & $\checkmark$ & $\checkmark$ & La Rioja, Jujuy & $\begin{array}{l}\text { Quebrada de la Cébila, } \\
\text { Coiruro deposit, } \\
\text { Rinconada }\end{array}$ & Lavandaio (1999a) & $\begin{array}{l}\text { Lead Acid Battery } \\
\text { Recycling }\end{array}$ \\
\hline Barite & $\begin{array}{l}85 \% \text { is used for the oil \& gas } \\
\text { sector (as drilling mud); to a } \\
\text { lesser extent for paintings, etc. }\end{array}$ & $\checkmark$ & $\checkmark$ & $\begin{array}{c}\text { Salta, Jujuy, } \\
\text { Neuquén, Mendoza }\end{array}$ & $\begin{array}{l}\text { Deposits in Cordillera } \\
\text { Oriental (Salta, Jujuy), } \\
\text { Cuenca Neuquina, etc. }\end{array}$ & $\begin{array}{l}\text { Brodtkorb et al. (1999); } \\
\text { Gozalvez et al. (2004) }\end{array}$ & $\begin{array}{l}\text { Generally neither } \\
\text { reused nor } \\
\text { recycled }\end{array}$ \\
\hline Beryllium & $\begin{array}{lll}\begin{array}{l}\text { Alloy in aerospace } \\
\text { defense, and } \\
\text { electronics industries }\end{array} & \text { and } \\
\end{array}$ & $\checkmark$ & $\checkmark$ & $\begin{array}{c}\text { San Luis, } \\
\text { Catamarca, } \\
\text { Córdoba, Tucumán }\end{array}$ & $\begin{array}{l}\text { Under-explored } \\
\text { resources in } \\
\text { pegmatites }\end{array}$ & Godeas et al. (1999) & $\begin{array}{l}\text { Recycled from } \\
\text { new industrial } \\
\text { scrap }\end{array}$ \\
\hline $\begin{array}{l}\text { Natural } \\
\text { borates }\end{array}$ & $\begin{array}{l}\text { Glass, fertilizer, chemicals, } \\
\text { neodymium-iron-boron } \\
\text { magnets for wind mills and } \\
\text { fiberglass insulation }\end{array}$ & $\checkmark$ & & $\begin{array}{l}\text { Puna (Salta, Jujuy), } \\
\text { Catamarca }\end{array}$ & $\begin{array}{l}\text { Hard borates in } \\
\text { Tincalayu, Sijes and } \\
\text { Loma Blanca and soft } \\
\text { in Salta, Jujuy and } \\
\text { Catamarca }\end{array}$ & $\begin{array}{l}\text { Alonso (1999) DAPM } \\
\text { (2018) Gozalvez et al. } \\
(2004)\end{array}$ & $\begin{array}{l}\text { They are not } \\
\text { recycled. } \\
\text { Recycling rate is } \\
\text { less than } 1 \%\end{array}$ \\
\hline Cobalt & $\begin{array}{l}\text { Super-alloys and catalysts. Of } \\
\text { importance for electric vehicle } \\
\text { batteries. }\end{array}$ & $\checkmark$ & $\checkmark$ & $\begin{array}{l}\text { La Rioja, San Luis, } \\
\text { Salta and } \\
\text { Catamarca }\end{array}$ & $\begin{array}{l}\text { Deposits King Tut, Las } \\
\text { Águilas, la Niquelina- } \\
\text { Esperanza, Fiambalá }\end{array}$ & $\begin{array}{c}\text { Bjerg and Sabalúa } \\
\text { (1999); Schamaluk and } \\
\text { Brodtkorb (1999) }\end{array}$ & $\begin{array}{l}\text { Recoverable from } \\
\text { industrial and } \\
\text { battery scrap }\end{array}$ \\
\hline Strontium & $\begin{array}{l}\text { Magnets, master alloys, } \\
\text { pigments, glass, zinc, etc. }\end{array}$ & $\checkmark$ & $\checkmark$ & $\begin{array}{l}\text { Neuquén and } \\
\text { Mendoza }\end{array}$ & $\begin{array}{l}\text { Deposits in Cuenca } \\
\text { Neuquina, Tábanos, } \\
\text { etc. }\end{array}$ & $\begin{array}{l}\text { Brodtkorb et al. (1999b); } \\
\text { Gozalvez et al. (2004) }\end{array}$ & $\begin{array}{l}\text { Recycling rate } \\
\text { less than } 1 \%\end{array}$ \\
\hline $\begin{array}{l}\text { Fluorspar } \\
\text { (fluorite) }\end{array}$ & $\begin{array}{l}\text { Hydrofluoric acid (refrigerant), } \\
\text { glass, ceramic, metallurgy, } \\
\text { steel and iron industry }\end{array}$ & $\checkmark$ & $\checkmark$ & $\begin{array}{l}\text { Catamarca, La } \\
\text { Rioja, San Juan } \\
\text { and other }\end{array}$ & $\begin{array}{l}\text { Deposits in Sierras } \\
\text { Pampeanas and La } \\
\text { Rioja, Cerro Pata de } \\
\text { Indio in San Juan }\end{array}$ & $\begin{array}{l}\text { Gozalvez et al. (2004); } \\
\text { Zappettini (1999a) }\end{array}$ & $\begin{array}{l}\text { Dissipative use. } \\
\text { Recycling rate } \\
\text { less than } 1 \%\end{array}$ \\
\hline $\begin{array}{l}\text { Natural } \\
\text { graphite }\end{array}$ & $\begin{array}{l}\text { Production of steel, electrodes, } \\
\text { refractories, batteries (active } \\
\text { anode) }\end{array}$ & $\checkmark$ & $\checkmark$ & La Rioja & Deposits in Villa Unión & Lavandaio (1999b) & $\begin{array}{l}\text { Low recycling } \\
\text { rate (less than } \\
3 \%)\end{array}$ \\
\hline Indium & $\begin{array}{l}\text { Indium-tin oxide for electronic } \\
\text { displays, liquid crystal, etc. }\end{array}$ & $\checkmark$ & $\checkmark$ & Santa Cruz & $\begin{array}{l}\text { Deposits in Macizo del } \\
\text { Deseado }\end{array}$ & Jovic et al. (2015) & $\begin{array}{l}\text { Industrial scrap } \\
\text { recycling }\end{array}$ \\
\hline Lithium & $\begin{array}{l}\text { Rechargeable batteries, glass } \\
\text { and ceramics, etc. }\end{array}$ & $\checkmark$ & $\checkmark$ & $\begin{array}{c}\text { Jujuy, Salta, } \\
\text { Catamarca, San }\end{array}$ & $\begin{array}{l}\text { Brine deposits in Puna } \\
\text { and pegmatites in }\end{array}$ & $\begin{array}{l}\text { DNPM (2019) Jerez } \\
\text { et al. (2017) }\end{array}$ & $\begin{array}{l}\text { Only recycled } \\
\text { from Li-ion }\end{array}$ \\
\hline
\end{tabular}

"Visión de Futuro" Año 19, Volumen No 26 Nº 1, Enero - Junio 2022 - Pág 105 - 122

URL de la Revista: http://visiondefuturo.fce.unam.edu.ar/index.php/visiondefuturo/index

URL del Documento: https://visiondefuturo.fce.unam.edu.ar/index.php/visiondefuturo/issue/view/22

ISSN 1668 - 8708 - Versión en Línea

E-mail: revistacientifica@fce.unam.edu.ar 


\begin{tabular}{|c|c|c|c|c|c|c|c|}
\hline \multirow[t]{3}{*}{ Material } & \multirow{3}{*}{$\begin{array}{l}\text { Main uses, including } \\
\text { relevance to the energy } \\
\text { transition }\end{array}$} & \multirow[t]{3}{*}{$\begin{array}{l}\text { EC list } \\
(2020)\end{array}$} & \multirow[t]{3}{*}{$\begin{array}{l}\text { US list } \\
(2018)\end{array}$} & \multicolumn{3}{|c|}{$\begin{array}{c}\text { Primary resources } \\
\text { (geological-mining potential) }\end{array}$} & \multirow{3}{*}{$\begin{array}{c}\begin{array}{c}\text { Secondary } \\
\text { resources }\end{array} \\
\text { batteries } \\
\end{array}$} \\
\hline & & & & \multicolumn{2}{|c|}{ Provinces with greater potential, examples } & \multirow[t]{2}{*}{ Source } & \\
\hline & & & & Luis, Córdoba & Córdoba and San Luis & & \\
\hline $\begin{array}{l}\text { Platinum } \\
\text { group } \\
\text { metals }\end{array}$ & $\begin{array}{l}\text { Catalysts, electroplating, fuel } \\
\text { cells and hydrogen } \\
\text { technologies }\end{array}$ & $\checkmark$ & $\checkmark$ & San Luis & $\begin{array}{l}\text { Las Águilas } \\
\text { polymetallic deposit }\end{array}$ & $\begin{array}{l}\text { Bjerg and Sabalúa } \\
(1999)\end{array}$ & $\begin{array}{l}\text { Recycled from } \\
\text { vehicle catalysts }\end{array}$ \\
\hline Niobium & $\begin{array}{l}90 \% \text { is used for high-strength } \\
\text { steels, superconducting } \\
\text { magnets, etc. }\end{array}$ & $\checkmark$ & $\checkmark$ & Salta & El Quemado district & $\begin{array}{l}\text { Gallisky and de Upton } \\
\text { (1993) }\end{array}$ & Low recycling \\
\hline Potash & $\begin{array}{l}\text { Fertilizer and other diversified } \\
\text { industrial uses }\end{array}$ & & $\checkmark$ & $\begin{array}{c}\text { Neuquén, } \\
\text { Mendoza, Puna }\end{array}$ & $\begin{array}{l}\text { Huitriniana and } \\
\text { Mendoza potash basin }\end{array}$ & $\begin{array}{l}\text { Gabriele (1999) Jérez } \\
\text { et al. (2019) }\end{array}$ & Not recyclable \\
\hline Tantalum & $\begin{array}{l}\text { Capacitors, super alloys, } \\
\text { robotics, artificial intelligence, } \\
\text { etc. }\end{array}$ & $\checkmark$ & $\checkmark$ & Salta and San Luis & $\begin{array}{l}\text { Districts El Quemado } \\
\text { and la Estanzuela }\end{array}$ & Gallisky (1999) & $\begin{array}{l}\text { Recyclable, low } \\
\text { recycling rate }\end{array}$ \\
\hline $\begin{array}{l}\text { Rare } \\
\text { earths }\end{array}$ & $\begin{array}{l}\text { Catalysts, glass, magnets, } \\
\text { medicine, etc. }\end{array}$ & $\checkmark$ & $\checkmark$ & $\begin{array}{l}\text { San Luis, Jujuy, } \\
\text { Salta and S. del } \\
\text { Estero }\end{array}$ & $\begin{array}{l}\text { Rodeo de los Molles, } \\
\text { Puna and Cordillera } \\
\text { Oriental, Jasimampa, } \\
\text { Rangel }\end{array}$ & $\begin{array}{l}\text { Lira et al. (1999) } \\
\text { Zappettini (1999b) }\end{array}$ & $\begin{array}{l}\text { Yttrium and } \\
\text { Europium are } \\
\text { recycled }\end{array}$ \\
\hline Titanium & $\begin{array}{l}\text { Pigments, polymers, } \\
\text { aerospace uses, medicine, etc. }\end{array}$ & $\checkmark$ & $\checkmark$ & $\begin{array}{c}\text { Catamarca, Buenos } \\
\text { Aires }\end{array}$ & $\begin{array}{l}\text { Cerro Cascabel and C. } \\
\text { Rico, sands in Litoral }\end{array}$ & $\begin{array}{c}\text { Schamaluk and Curci } \\
(1999)\end{array}$ & $\begin{array}{l}19 \% \text { recycling } \\
\text { rate }\end{array}$ \\
\hline $\begin{array}{l}\text { Tungsten } \\
\text { (wolfram) }\end{array}$ & $\begin{array}{l}\text { Cemented carbides, hard tool } \\
\text { alloys }\end{array}$ & $\checkmark$ & $\checkmark$ & $\begin{array}{l}\text { San Luis, Córdoba, } \\
\text { La Rioja, Jujuy, etc. }\end{array}$ & $\begin{array}{l}\text { Tusaquillas (Jujuy), } \\
\text { Ambul and Santa Rosa } \\
\text { (Córdoba), Sierra } \\
\text { Velasco (La Rioja), etc. }\end{array}$ & $\begin{array}{l}\text { Brodtkorb and Ortiz } \\
\text { Suarez (1999) }\end{array}$ & $\begin{array}{l}\text { Recycling rate } \\
\text { close to } 40 \%\end{array}$ \\
\hline Uranium & $\begin{array}{l}95 \% \text { is used for fuel in nuclear } \\
\text { reactors }\end{array}$ & & $\checkmark$ & $\begin{array}{l}\text { Chubut, Salta } \\
\text { Mendoza, Río } \\
\text { Negro }\end{array}$ & $\begin{array}{l}\text { Various advanced } \\
\text { projects }\end{array}$ & $\begin{array}{l}\text { DNPM (2019) Such et } \\
\text { al. (2016) }\end{array}$ & Low recyclability \\
\hline $\begin{array}{l}\text { Vanadiu } \\
\mathrm{m}\end{array}$ & Alloys, special steels & $\checkmark$ & $\checkmark$ & $\begin{array}{l}\text { Córdoba, Neuquén, } \\
\text { Río Negro }\end{array}$ & $\begin{array}{l}\text { El Guaico, Tordillo, } \\
\text { Amarillo Grande }\end{array}$ & Candiani (1999) & $\begin{array}{c}\text { Medium } \\
\text { recyclability }\end{array}$ \\
\hline
\end{tabular}

“Visión de Futuro" Año 19, Volumen No 26 No 1, Enero - Junio 2022 - Pág 105 - 122

URL de la Revista: http://visiondefuturo.fce.unam.edu.ar/index.php/visiondefuturo/index

URL del Documento: https://visiondefuturo.fce.unam.edu.ar/index.php/visiondefuturo/issue/view/22

ISSN 1668 - 8708 - Versión en Línea

E-mail: $\underline{\text { revistacientifica@fce.unam.edu.ar }}$ 
Regarding lithium, in recent years and linked to the projections of a growing future demand for batteries for electric vehicles, the metal has become one of the main recipients of exploratory investment in Argentina (Such, 2018). Although some provinces such as Jujuy have declared it a "strategic" natural resource, the Mining Code (law 1919/1886) considers it an ordinary mineral that can be given in concession to private parties without requiring special conditions, for example regarding technology transfer and/or added value. Under such legal framework, lithium is extracted by multinational companies that export it as a commodity and maintain links with the local productive network that are not knowledge intensive (Marín et al., 2015).

In the current context, lithium reserves still represent a special opportunity to link the scientific system with the productive one and overcome the commodity export policy that underpins it. This opportunity has been expressed by the Interuniversity Forum of Lithium Specialists, which constitutes the main federal network of lithium expert scientists in Argentina. According to a recent statement from the Forum ${ }^{13}$, its objective is to promote the addition of value in the lithium chain both "downstream" (production of lithium derivatives, battery manufacturing) and "upstream" (development of suppliers for exploration and processing, for example through co-production).

Currently from the national government there is a renewed impulse to advance "downstream" in the lithium value chain through strategic agreements with China (Once Diario, 2021a), the bill to promote Sustainable Mobility and the inclusion of mining as a social objective of the company Integración Energética Argentina SA. Although the promotion of "downstream" linkages has been a traditional objective of developmental policies for years, in the case of lithium, recent studies have shown that in Argentina the promotion of backward linkages (or "upstream") has greater potential and faces obstacles less important than the search for forward linkages (López et al., 2019; Obaya et al., 2020; Obaya and Pascuini, 2020). These obstacles include the need for planning, accumulation of experience and capital, strengthening state capacities, linking the production network with the national innovation system, among others (Roger et al., 2017).

At the same time, the extraction of lithium in Argentina entails important social and environmental challenges, such as the adequate implementation of prior, free and informed consultation with indigenous communities ${ }^{14}$ (Gómez, 2019) and the impacts on the regional

13 See https://www.cin.edu.ar/download/comunicado-del-foro-interuniversitario-de-especialistas-enlitio-de-la-argentina-marzo-2020-pdf/

${ }^{14} \mathrm{~A}$ fundamental human right of a collective nature. Consultation is required according to ILO Convention 169 (Law 24.071/92) framed in the United Nations Declaration and the American Declaration on the Rights of Indigenous Peoples.

"Visión de Futuro" Año 19, Volumen N²6 N 1, Enero - Junio 2022 - Pág 105 - 122

URL de la Revista: http://visiondefuturo.fce.unam.edu.ar/index.php/visiondefuturo/index

URL del Documento: https://visiondefuturo.fce.unam.edu.ar/index.php/visiondefuturo/issue/view/22

ISSN 1668 - 8708 - Versión en Línea

E-mail: revistacientifica@fce.unam.edu.ar 
water balance and on the wetlands hydrologically connected to the salt flats (Sticco et al., 2019). Such aspects require further investigation (Mignaqui, 2019) and they represent key areas for a closer link between the scientific and productive systems. Like the water footprint, the carbon footprint is relevant to the competitiveness of lithium. Automotive companies demand the reduction of their carbon footprint and prioritize companies that can prove it. $A$ recent example in Catamarca is the case of the BMW company, which chose Livent as one of its lithium suppliers because its lithium production generates $25 \%$ lower greenhouse gases than other production methods (Once Diario, 2021b).

Other critical minerals of importance are antimony, barite, celestine (main source of strontium), fluorite, platinum group metals and natural graphite. For the first three, there is a historical record of production in open pit mining operations and underground workings. Barite has been extracted in the past in the provinces of Jujuy, Mendoza and Neuquén, while celestine is exclusive to the Neuquina Basin (Lavandaio and Catalano, 2004). Fluorite occurs in widely distributed deposits throughout the national territory. In the past, there was fluorite mining in Catamarca, Córdoba, San Juan, Mendoza, Río Negro and Chubut. Antimony, platinum group metals, and natural graphite have not been the subject of recent exploration efforts or significant mining. At the same time, there is a lack of studies that allow us to understand what measures are necessary for their extraction to be economically possible and what their potential is in terms of being able to substitute imports and build upon local linkages.

With regard to tantalum and tungsten, there are historical antecedents of tantalum (and columbium) production for iron and steel use in San Luis and Córdoba, although of greater importance were the tungsten (wolfram) operations in the provinces of La Rioja, Catamarca, Córdoba, San Juan, Mendoza and San Luis. Unlike these minerals, no historical extraction data for titanium or niobium are known (Lavandaio and Catalano, 2004). Tungsten is the most economically important critical raw material according to the latest evaluation of critical raw materials by the European Commission and, like tantalum and titanium, its demand is expected to continue to increase.

Other critical metals in Table $N^{\circ} 1$ of great importance but with little knowledge of their geological-mining potential are the group of metals produced as by-products, which include beryllium, cobalt, indium and rare earths. These metals are produced in mines in the form of by-products of main metals ${ }^{15}$ such as copper, lead and zinc, nickel, iron, manganese, chromium, etc. By-products are not the main driver of a mining project but are produced as an additional according to the possibilities of the process flowsheet and metallurgical

\footnotetext{
${ }^{15}$ See the interconnections according to the metal wheel in Reuter (2005).

"Visión de Futuro" Año 19, Volumen N²6 N 1, Enero - Junio 2022 - Pág 105 - 122

URL de la Revista: http://visiondefuturo.fce.unam.edu.ar/index.php/visiondefuturo/index

URL del Documento: https://visiondefuturo.fce.unam.edu.ar/index.php/visiondefuturo/issue/view/22

ISSN 1668 - 8708 - Versión en Línea

E-mail: revistacientifica@fce.unam.edu.ar
} 
recovery of each mine. Historical antecedents in Argentina include the production of beryllium at the Las Tapias mine (Córdoba) and cobalt at the King Tut mine (La Rioja), with no known production of rare earths in the country. Regarding the mineral indium, which is obtained as a by-product of zinc, it is scarcely studied from the genetic and mining point of view. Its discovery is recent and has occurred in epithermal polymetallic deposits in the Deseado Massif (for example, in the Pingüino project). This indicates that there is still great potential in other deposits in Patagonia with similar characteristics which have not been geochemically analysed for indium or in which the necessary analytical procedures have not been used to determine its presence (Jovic et al., 2015).

Uranium is another mineral acknowledged as critical since nuclear energy, although it cannot be considered a "clean energy source"16, generates very low greenhouse gas emissions. In turn, there are uranium projects that can generate critical minerals as byproducts, for example rare earths or vanadium (see Amarillo Grande project). In Argentina, uranium has not been mined to produce concentrate since 1997 and, since then, the three nuclear power plants have operated with imported raw material (Such et al., 2016). The potential reactivation of uranium deposits in Mendoza or Chubut has the potential to substitute imports of uranium products necessary for all nuclear technology production, research and development activities. This potential is restricted by several factors. At the political level, although the current government is promoting nuclear energy through agreements with China ${ }^{17}$, in exercises carried out within the framework of the Platform "Energy Scenarios Argentina 2040"18 (in which multiple actors participated, including government), nuclear generation was in general little incorporated by most scenario designers (Beljansky et al., 2018). From a social point of view, the reactivation of uranium deposits in Mendoza or La Rioja should confront opposition from social movements. These movements reject uranium mining due to the risk of generating pollution during the operation and/or after the mine closure, a perception influenced, among other factors, by the existence of mining environmental liabilities in old uranium mines (Brúculo, 2019; Wagner, 2008).

Potash, which is $90 \%$ used as a fertilizer, has high potential as global consumption is increasing and demand is expected to increase driven by a greater need for fertilizers for food production. Argentina has high potential in the Altiplano-Puna salt flats and in the Huitriniana Basin deposits, which make up the most important potash basin in Latin America and one of the largest in the world. In Argentina, the current demand for potash for soil

\footnotetext{
16 Due to the generation of nuclear waste and the need for its long-term storage.

17 See news regarding the first Five-Year Plan (2017-2021) between China and Argentina to advance with the Atucha III plant in https://www.fundeps.org/argentina-centrales-nucleares/

18 See https://escenariosenergeticos.org/

"Visión de Futuro" Año 19, Volumen No 26 No 1, Enero - Junio 2022 - Pág 105 - 122

URL de la Revista: http://visiondefuturo.fce.unam.edu.ar/index.php/visiondefuturo/index

URL del Documento: https://visiondefuturo.fce.unam.edu.ar/index.php/visiondefuturo/issue/view/22

ISSN 1668 - 8708 - Versión en Línea

E-mail: revistacientifica@fce.unam.edu.ar
} 
fertilization is low, which discourages its extraction for soil fertilization. However, all local production of potash fertilizers is made with imported potassium and practically all domestic consumption comes from imports. These characteristics of the Argentine market indicate the possibility that national production could be used to substitute (imported) potash for the production of fertilizers and for their export.

However, this potential is restricted by the need to improve transportation logistics from deposits to consumption centers, given that current prices do not compensate for production costs or the return on investment (Jérez et al., 2019). In the case of the Potasio Río Colorado deposit (hereinafter PRC), a railway corridor project called the train "Norpatagónico" is currently under discussion, which would connect the port of Bahía Blanca with the Vaca Muerta deposit and could serve to export potash from said project. Although the works to adapt the railway infrastructure and purchase of machinery for the PRC project open an opportunity for local suppliers, including the railway industry, this requires active policies to prevent inputs from being imported using the benefits provided in Law 24,196/93 (Fabrizio, 2010).

Another great challenge regarding potash deposits, for example in Mendoza, has been the social license for large projects like PRC. In this case, the social opposition is mainly due to the fear of the salinization of the Colorado River caused by the residues (salt tailings) left by the extraction of potash in the mine area, in an arid area where water has a strategic value (Wagner and Giraud, 2011). A possible solution to this risk could come from the use of new technologies, such as that developed by the Canadian company Gensource Potash for the Tugaske project. Such extractive method does not produce salt tailings as waste and does not require surface brine ponds (Ruiz Leotaud, 2020).

Last but not least it is worth mentioning hydrogen, a clean fuel with great potential in Argentina for the production of gray hydrogen (from oil and coal), blue (from natural gas, currently the cheapest option) and green from intermittent renewable energies (wind, solar). Hydrogen production and storage technology has been under investigation in Argentina since the 1970s and milestones have been achieved such as the experimental plant in Pico Truncado, the pilot plant in Antarctica and the electrolytic hydrogen pilot plant of the Hychico company in Chubut, which produces green hydrogen from the energy generated by the Diadema wind farm (Bolcich, 2018). With regard to storage, the experimentation of the Hychico company with the underground mode and advances in the development of fuel cells (Serquis, 2020) can be mentioned. Also noteworthy is the 2020 launch of the H2ar consortium, led by the Y-TEC company. Although in Argentina the technology is still in a very initial phase and does not have the involvement of the mining sector, at a global level said

\footnotetext{
"Visión de Futuro" Año 19, Volumen N²6 No 1, Enero - Junio 2022 - Pág 105 - 122

URL de la Revista: http://visiondefuturo.fce.unam.edu.ar/index.php/visiondefuturo/index

URL del Documento: https://visiondefuturo.fce.unam.edu.ar/index.php/visiondefuturo/issue/view/22

ISSN 1668 - 8708 - Versión en Línea

E-mail: revistacientifica@fce.unam.edu.ar
} 
sector works in an associative manner to accelerate developments in mining equipment (Mitchell, 2020). In Chile, the Ministry of Energy identified that the mining sector could benefit from the production of green hydrogen in copper projects and use it for combined use in dual combustion engines, fuel cells for passenger transport and energy backup systems (Vásquez and Salinas, 2019). Unlike Chile, in Argentina the mining sector still does not have similar experiences or evaluations of potential.

\section{Secondary materials (recycling, re-use)}

When making an approximation to the potential of critical minerals that could be recovered from secondary sources, it is necessary, in the first place, to point out the lack of data in this regard. This is the result of the absence of a statistical system that generates and publishes data on the characteristics of solid waste that enters final disposal circuits (and those that do not enter). Although there are jurisdictions such as the Autonomous City of Buenos Aires or Mendoza that quantify the generation of urban solid waste relevant in terms of critical minerals, such as waste from electrical and electronic equipment (hereinafter WEEE), there is no statistical federal system to know the volume generated, collected and entered into formal recycling circuits.

Secondly, it is necessary to highlight that although there are jurisdictions that have enacted laws for the integral management of urban solid waste, informally known as "zero waste" laws (Autonomous City of Buenos Aires, La Plata, Rosario, etc.), moving forward towards more closed cycles of waste management is still very incipient. According to a study by the Ministry of the Environment and Sustainable Development of the Nation, $42 \%$ of the country's municipalities have solid waste separation plants but only $8.3 \%$ have an operational plant (Telam, 2017). In Buenos Aires, only $6 \%$ of the waste produced is recovered (Rocha, 2017).

Acknowledging such limitations, it can be pointed out that there is an unknown potential of critical minerals recoverable from WEEE. Since there are no companies in Argentina with the technology to recover critical minerals, there are others that are dedicated to the collection and shipment to recovery plants in Europe, such as the Pelco Group. However, beyond WEEE, there is also the potential for recycling antimony and cobalt (from exhausted batteries), platinum group metals (associated with the recycling of motor vehicles, their lead acid batteries and catalysts) and tungsten and vanadium (from steel).

Regarding lead-acid batteries, in Argentina it is estimated that 4.5 million are discarded annually, which could enter the formal recycling circuit in order to recycle their components, lead being the metal of greatest interest. However, the percentage of batteries entering the

\footnotetext{
"Visión de Futuro" Año 19, Volumen N²6 N 1, Enero - Junio 2022 - Pág 105 - 122

URL de la Revista: http://visiondefuturo.fce.unam.edu.ar/index.php/visiondefuturo/index

URL del Documento: https://visiondefuturo.fce.unam.edu.ar/index.php/visiondefuturo/issue/view/22

ISSN 1668 - 8708 - Versión en Línea

E-mail: revistacientifica@fce.unam.edu.ar
} 
formal circuit is not known (SAyDS and MPyT, 2018). Beyond that, of those that do enter, only lead and plastics are recycled, without recovering critical metals such as antimony or cobalt. This is due to the fact that in general the business model of companies and the regulatory framework, designed from a linear perspective ("from the cradle to the grave"), prioritize the perspective of hazardous waste under the Basel Convention and its adequate final disposition.

Regarding tungsten, it has great potential to be recovered from the tungsten carbide contained in the bit cones used for the oil and mining industry, in catalysts and conveyor belts. The tungsten contained in these residues has a high economic value as it is more concentrated than in the mineral extracted by mining. Although tungsten does not appear prioritized in the national circular economy plans, such as in the National Action Plan for Industry and Climate Change, it has gained prominence in the circular economy tables implemented by the Ministry of Productive Development.

Another as yet unknown polymetallic potential is found in the waste from old mining operations. Usually, the perspective that has prevailed with respect to mining waste has been that of environmental safety, that is, prioritizing the closure, safety and physical-chemical stability of mining sites. In spite of that, in Argentina there are numerous cases of mining operations that were improperly closed and became a mining environmental liability, such as the cases of Abra Pampa in Jujuy (now remediated) or San Antonio Oeste in Río Negro (partially remediated). However, in addition to the environmental dimension, mining authorities must consider the possibility of recovering valuable metals. An example in Argentina is the Mina Martha project (Santa Cruz) where precious metals were obtained by retreating the waste stored in the tailings dam. A first step in this direction is to evaluate the potential in old mining facilities, which involves carrying out a mineralogical and geochemical characterization of the content and volume of the historical resources housed in waste rock and tailings dams' storage facilities. Said characterization should follow a standard methodology similar to the cubing of resources and reserves in primary deposits, which would allow quantifying the contained and recoverable materials, including critical minerals.

Another necessary step is that both the authorities in charge of the inventories as well as those technical support organizations are aware of the latest available and developing (emerging) technologies for the revaluation of mining waste. For example, in relation to uranium mining liabilities, there are new investigations that open possible paths for the recovery of niobium, titanium and tantalum from the tailings of uranium production (Mendez et al., 2018). A recent study in the UK discovered the possibility of treating depleted uranium (residue) as a catalyst to convert ethylene to ethane. This opens the possibility of using the 
chemical products resulting from the process for power generation (Tsoureas et al., 2020).

\section{Policies to promote the integral use of critical materials under sustainability principles}

In Argentina, advancing the agenda of a more efficient use of critical materials implies a comprehensive use of primary and secondary deposits, for which legislative, political, economic and socio-cultural challenges must be faced. Suggestions and policy recommendations for overcoming them are outlined below.

First, at the level of mining authorities, it is necessary to lead the modernization of mining policies (national and provincial) based on international trends, starting with their alignment with the SDGs agenda. This implies, within the framework of the Strategic Planning of the National Mining Secretariat (Resolution 47/2020), advancing with priorities such as the decarbonization of the energy matrix, improving the quality of the public consultation processes and promoting the development of suppliers in strategic sectors such as renewable energy, software and certification, for example of the carbon and water footprint (of special relevance for lithium mining).

Second, it is imperative to improve awareness of available materials and their visibility to potential investors. Regarding primary resources, it is essential to move forward with taxbased incentives to promote advanced exploration targeting critical minerals, for example within the benefits provided by law 24,196/93 or through special incentives, e.g., similar to the flow-through shares in Canada (Murguía, 2019). Likewise, it is necessary to further promote cooperation and complementation of the private sector with the science and technology system in order to establish synergies in the exploration of critical minerals, as exemplified by the discovery of the mineral indium in the Deseado Massif. It is also necessary to improve the quality of pre-competitive geoscience information (geospatial database with exploration results) with an emphasis on critical minerals. Regarding secondary resources, it is necessary to work on agreements between the authorities for the creation of statistical systems for the generation of data and indicators on the amount of waste generated (e.g., at the municipal level) and its potential to recover critical minerals.

In relation to mining waste, it would be desirable for existing mining environmental liability inventory projects to include standardized methods for analytical sampling of the recovery potential of critical elements. For this, there is potential for synergies and collaboration between national and foreign mining authorities and researchers from the national science and technology system. For example, authorities could cooperate with the International Center of Excellence SMI-ICE-Chile, which held a first workshop in 2019 to advance in the development of a reliable, fast and low-cost methodology to characterize

\footnotetext{
“Visión de Futuro" Año 19, Volumen N²6 N 1, Enero - Junio 2022 - Pág 105 - 122

URL de la Revista: http://visiondefuturo.fce.unam.edu.ar/index.php/visiondefuturo/index

URL del Documento: https://visiondefuturo.fce.unam.edu.ar/index.php/visiondefuturo/issue/view/22

ISSN 1668 - 8708 - Versión en Línea

E-mail: revistacientifica@fce.unam.edu.ar
} 
mining waste. In Chile, the JRI-Ecometales Consortium is also relevant, which published a manual for reprocessing mining tailings. In Spain, an example of recovery and valorization of mining waste is that of the Penouta mine from whose tailings and waste rock tantalum and niobium are being recovered (Blengini et al., 2019).

Third, it is necessary to prioritize the efficiency dimension and move from a perspective focused on primary minerals ("mining policies") towards a comprehensive use of materials ("mineral policies"). For this, the national scientific system has a role to play as a partner of the corporate sector to promote co-production in primary deposits and/or in the creation of innovative industrial processes to recover critical minerals, for example to recover antimony and cobalt from depleted lead-acid batteries. In Europe the research project "NUOVOPb"19 managed to separate materials in spent lead-acid batteries and recover them through a hydrometallurgical recycling process. This process makes it possible to produce lead oxide at an initial cost of one seventh of the existing recycling methods.

Fourth, it is suggested to modernize ("circularize") not only the policies but also the normative frameworks that regulate production systems, which have been forged under linear perspectives and usually do not consider waste as a potential raw material. This is necessary to regulate the handling of substances that environmental authorities consider highly dangerous due to their toxicity (e.g., chromium, beryllium) which are valued by the electronic and digital industries (Fernández Protomastro, 2013). In order to move forward with recycling, a first step is to improve the efficiency of collection through incentives to end users for separation at source, the formalization of workers in the sector, and the introduction of extended producer responsibility in the legal framework. Another important step to boost the recovery of lead from lead-acid batteries is the reform of the Hazardous Waste Law $24.051 / 91$ to enable the recovery of waste streams together with an increase in formal distribution channels and greater transparency in the market (SAyDS and MPyT, 2018).

Fifth, the recovery of secondary metals (both critical and non-critical, for example gold from WEEE) requires the construction of technological capacities and development of new processes adapted to the context conditions of local companies. Financial compensation mechanisms are also necessary for recycling companies so that they can have predictability and income stability, especially in low metal price cycles.

Sixth, the training of the different actors in the value chain on opportunities regarding critical minerals is essential. Said training must be complemented by processes of linking and transferring knowledge on existing and developing technologies between mining authorities, mining companies, suppliers and the national science, technology and innovation

\footnotetext{
${ }^{19}$ See https://cordis.europa.eu/article/id/386817-a-revolution-for-lead-acid-batteries-recycling/es "Visión de Futuro" Año 19, Volumen $N^{0} 26$ No 1, Enero - Junio 2022 - Pág 105 - 122 URL de la Revista: http://visiondefuturo.fce.unam.edu.ar/index.php/visiondefuturo/index URL del Documento: https://visiondefuturo.fce.unam.edu.ar/index.php/visiondefuturo/issue/view/22 ISSN 1668 - 8708 - Versión en Línea 
system. The latter, together with the provincial systems, could seek a greater alignment of research agendas with the needs of the mining and environmental authorities and prioritize critical minerals in the strategic issues of organizations such as CONICET. In turn, it is recommended that national plans that include the circular economy, for example the National Action Plan for Industry and Climate Change, turns the attention to opportunities around the extraction and/or recovery of critical minerals, such as cobalt.

Finally, regarding the issue of supplier development and value chain, recent studies have detected a low level of cooperation between public research institutions (especially universities), companies and mining authorities (Marín et al., 2020). This indicates the need to seek a high-level articulation to promote lines of research focused on the mining value chain and on which are the segments with the greatest possibilities for the entry of national suppliers, especially in consideration of opportunities related to critical minerals.

\section{CONCLUSIONS}

The identification of minerals as "critical" by different international organizations makes more visible their market importance and opens opportunities for resource-rich countries. Although great potential is presumed, the Argentine State does not yet have a federal system of updated and standardized data that allows knowing the potential of critical minerals contained and recoverable in primary and secondary resources. At the same time, Argentina has not developed a specific policy or strategy for the use of this type of materials.

The comprehensive use of critical (and non-critical) minerals under sustainability principles requires national and provincial authorities to coordinate actions to promote not only policies but also quality multi-stakeholder dialogue processes. These spaces should be useful for the exchange of business and training opportunities, but also for the exchange of data, information and arguments between actors with heterogeneous positions on what to do with mineral resources. At the same time, they should allow the generation of consensual strategies for the use of natural resources as a platform for innovation and industrial development based on domestic scientific and technological capacities. The competitiveness of critical minerals depends not only on the profitability of future projects but also on a structural change in how resources are managed, what they are extracted for, and how and who participates in the decision-making processes.

\footnotetext{
“Visión de Futuro" Año 19, Volumen N²6 N 1, Enero - Junio 2022 - Pág 105 - 122

URL de la Revista: http://visiondefuturo.fce.unam.edu.ar/index.php/visiondefuturo/index

URL del Documento: https://visiondefuturo.fce.unam.edu.ar/index.php/visiondefuturo/issue/view/22

ISSN 1668 - 8708 - Versión en Línea

E-mail: revistacientifica@fce.unam.edu.ar
} 


\section{REFERENCES}

Please refer to articles in Spanish Bibliography.

\section{BIBLIOGRAPHICAL ABSTRACT}

Please refer to articles Spanish Biographical abstract. 